\title{
Women and market garden production in Benin republic
}

\begin{abstract}
This paper highlights the status of women as well as their involvement in the activities related to market gardening in Benin. The data collected in this study come from two main sources. The first part of the data was collected from some vegetable producers cooperatives through semi-structured interviews and focus groups. Information gathering was conducted from north to south of Benin on nine different research sites with leaders of 54 producer associations through interviews. these groups were chosen in a reasoned way, ensuring that they are composed of both women and men. The second part of the data was obtained from the directions of the human resources departments of the Ministry of Agriculture, Livestock and Fisheries and completed by those obtained from the Ministry of Public Labor. The descriptive statistics were performed with the SPSS software. The discourse analysis was utilized as a method of analysis of all the information gathered from both producer groups that government institutions. This paper came out that women are involved in farmers associations as well as government institutions in connection with the agricultural sector Although it is obvious, they are not sufficiently represented as men in these different entities and are not really involved in decision making processes. It is therefore imperative to bridge the gap between men and women in agriculture generally and market gardening especially. To this end, it is significant to develop policies and a regulatory framework to fight gender inequality. This will ensure equal access to resources, and the same support through agricultural programs and projects. In turn, this will improve women membership to farmers associations and their representativeness in government institutions.
\end{abstract}

Volume 3 Issue 4 - 2019

\author{
Miassi Yann Emmanuel,' Dossa Fabrice Kossivi,² \\ Sinasi Akdemir' \\ 'Department of Agricultural Economics, Faculty of Agriculture, \\ University of Cukurova,Turkey \\ +Department of Agricultural Economics, Faculty of Agriculture, \\ University of Nigeria, Nigeria
}

Correspondence: Miassi Yann Emmanuel, Department of Agricultural Economics, Faculty of Agriculture, University of Cukurova, 0I330 Bacali,Adana, Turkey,

Email yannmanu006@gmail.com

Received: July 23, 2019 | Published: August 09, 2019

Keywords: benin, development, gender, rural area

\section{Introduction}

The question of gender and rural development has attracted the attention of more than one for years and continues to be a contemporary subject. This thematic has been subject of several sessions (workshop, symposium, convention, etc.) and various activities all over the world. The fact that this issue is a global concern, resulting in the fact that disparities between men and women are seen everywhere on the various points of the globe. ${ }^{1}$ In Africa, specifically the west side, women are involved in a significant proportion of all agricultural activities. They are at the same time an essential part of the well-being of their families and the centerpiece of the future of their children. ${ }^{2}$ In Benin, like other West African countries, women are also heavily involved not only in garden activities but also in the marketing of harvesting products.

Agriculture, the mainstay of Benin's economy is the main activity of the population especially in rural areas where women represent $42.2 \%$ of $65.5 \%$ of assets. ${ }^{3}$ Women are active both within the farm operations and food processing activities where men are sometimes almost non-existent. ${ }^{4}$ Despite women are heavily used throughout the various links of the various value chains, they are not really gratified by merit that is supposed to be theirs by right. Unlike men, they do not have sufficient autonomy and their voice is hardly heard when it comes to decision making. However, it is important to solicit the participation of women in decisions that may directly or indirectly influence their living conditions. According to FAO estimates, ${ }^{5}$ Africa's population will increase from 820 million to 2 billion people, which means that farmers of Africa and mostly developing countries such Benin will have to double their food production. But making autonomous women to engage in decisions and equip them with the same inputs as men, could contribute more effectively to the fight against food insecurity. The complete development of a country and especially the agricultural sector require the maximum participation of women on equal terms with men. ${ }^{6}$ This article therefore deals with the involvement of women both in rural and government agricultural institutions.

\section{Analytical framework and methodology}

The data collected in this study come from two main sources. The first part of the data was collected from some vegetable producers cooperatives through semi-structured interviews and focus groups. Information gathering was conducted from north to south of Benin on nine different research sites with leaders of 54 producer associations through interviews. We have districts of Tori-Bossito, Toffo and Agbomey Calavi in the South; Save, Dassa and Glazoué in the Center; and Parakou, Bembereke and Malanville in northern Benin. The following table shows the distribution (Table 1).

These areas were selected because of the large number of associations of market gardeners they host, but also bearing in mind the heterogeneity of these associations. In other words, these groups were chosen in a reasoned way, ensuring that they are composed of both women and men. The descriptive statistics were performed with the SPSS software.

In addition, three focus groups bringing together representatives of groups as well as some other members have enabled a triangulation of information gathered during individual discussions. Drawing on the work of Diouf ${ }^{7}$ and then Houinsa, ${ }^{3}$ the talks focused primarily on women's adherence to various farmer associations (group, cooperative, etc.), then the role of women in these organizations and the level of involvement of women in decision-making in these groups. All data obtained from semi-structured interviews and focus groups were recorded and transcribed. This study therefore attempted to research and analyze:

The role of women in market gardening activities 


\section{The place of women in decision-making in the various organizations}

The second part of the data was obtained from the directions of the human resources departments of the Ministry of Agriculture, Livestock and Fisheries (MAEP) and completed by those obtained from the Ministry of Public Labor (MTP). The data obtained from these two different entities were related to statistics on the percentage of men and women officials in the Ministry of Agriculture and its decentralized structures. These figures also concerned the percentage

Table I Distribution of associations of men and women who are the heads of these institutions. Furthermore, six semi-structured interviews were organized with some female officials of these entities to evaluate the degree of involvement of women in decision-making within the government institutions. Talks focused on one hand on their missions within the structures in which they perform their duties and the other hand on their involvement in the processes of decision making. The discourse analysis was utilized as a method of analysis of all the information gathered from both producer groups that government institutions.

\begin{tabular}{llll}
\hline Area & District & Total number of associations surveyed & Average number of producers per group \\
\hline \multirow{3}{*}{ South } & Tori-Bossito & 5 & 12 \\
& Toffo & 4 & 25 \\
& Agbomey Calavi & 7 & 13 \\
\multirow{3}{*}{ Center } & Save & 3 & 18 \\
& Dassa & 9 & 18 \\
& Glazoué & 6 & 22 \\
\multirow{2}{*}{ North } & Parakou & 8 & 28 \\
& Bembereke & 3 & 33 \\
Total & Malanville & 9 & 27 \\
\hline
\end{tabular}

\section{The role of rural women in agricultural activities}

Women are very dynamic economic agents. ${ }^{8}$ They are called to ensure certain responsibilities that affect their ability to conduct economic activities (CTA 1999). In production, nearly $70 \%$ of the workforce is female. ${ }^{9}$ Women participate in planting, weeding, harvesting, processing, storage and the sale of crop products. ${ }^{7}$ Note that these works are carried out by women both in the family as a help given to some members, and at the request of a third person not belonging to his family or his immediate entourage. However, the labor force deployed by the latter constitutes a labor sold in exchange for money or crop products. To this end, woman is an important economic agent in the sense that by her activities, she creates value and wealth. Women in Benin's rural areas are engaged not only in cereal production (maize, soybean, sorghum, millet, etc.), but also cash crops like cotton and cashew nuts which are of some importance for the national economy by the income they generate. ${ }^{10}$ Women are also found in the production of food crops such as okra, pepper, tomato, large nightshade, pigweed and other products that are sold in local markets in order to feed their families. ${ }^{11}$ However, it appears imperative to note that despite the potential that has the woman and her contribution to the rural-based activities, she is not yet seen as an important lever of development of Beninese agricultural sector.

Table 2 Distribution of man and women in associations

\section{Status of Women and its involvement in the decision making process}

\section{The share of women in farmer's cooperatives and groups}

With the exception of women associations of producers, most of the cooperatives and mixed groups of market gardeners in Benin are men (only 7\% of women). This low rate of membership of women in various farmer associations, is due to selection criteria imposed by the Executive Office of the groups. One of the criteria to prevent more than $70 \%$ of women to belong to an association of producers, is the agreement of the head of household on the integration of women in the group. In other words, although they have the will, women without the consent of their husbands cannot belong to an association. Very few are the leaders of households allowing their wives to join associations. For them, women involved in the activities of a group are less devoted to the household. This is actually a completely outdated design because the woman should not be confined by a role of " housewife ". Women's group membership becomes for this purpose, unfortunately a privilege reserved for widows and those who could obtain the consent of their husbands. The following table shows the distribution of men and women in the groups (Table 2).

\begin{tabular}{lllll}
\hline Area & $\begin{array}{l}\text { Total number of } \\
\text { associations surveyed }\end{array}$ & $\begin{array}{l}\text { Average number of producers } \\
\text { per group }\end{array}$ & $\begin{array}{l}\text { Average percentage } \\
\text { of man }\end{array}$ & $\begin{array}{l}\text { Average percentage of } \\
\text { women }\end{array}$ \\
\hline South & 16 & 17 & 93,7 & 6,3 \\
Center & 6 & 19 & 89,4 & 10,6 \\
North & 7 & 29 & 95,8 & 4,2 \\
Total average & & 92,97 & 7,03 \\
\hline
\end{tabular}

Farmer's cooperatives and groups are all headed by an executive office defined in a chairperson, the vice-president, a permanent secretariat and an accountant. It was noted that the chairmanship of these associations has always been the prerogative of the producers of the male gender and that very few women are integrated into the executive offices. The few women who have had the privilege to join the executive board of their groups are mostly secretaries given their level of literacy. Also it should be noted that despite the fact that they occupy a position in the executive office of their group, their voice is hardly heard. Indeed, the decisions taken by the group members are usually organizational, structural and economic. As indicated at the beginning of this section, in addition to mixed associations, there are also women cooperatives and groups. These women's groups have emerged following the willingness of women to be heard and to enjoy full autonomy. Although they are better supported on technical, organizational and financial plans through development programs and projects, inequalities are still observed. 12 


\section{Women in government agricultural institutions}

The Ministry of Agriculture, Livestock and Fisheries (MAEP), highest authority in charge of the agricultural sector management of Benin is composed of four organs. These are the Directorate of Forecasting and Programming (DPP), the Directorate of Administration and Finance (DAF), the Directorate of Information and Records Center (DIP) and the minister's office. This entity is composed of a mixed staff from the perspective of gender; meaning that it has both men and women. However, women represent only $4 \%$ of staff based throughout the MAEP and its decentralized structures $2.5 \%$ of these women are in charge of administrative affairs such as secretariat management, email management, library management and the orientation of the users of its entities. Only $1.5 \%$ of these women are actively involved in the direction and influence decisions at general meetings and assemblies. These figures should raise a number of questions and at the same time, highlight the fact that women are not strongly represented at the heart of decision-making board. The position of Minister of Agriculture, head of different directions listed above are decades exclusive to executives of the male gender. Since the 60's until now, very few women have been assigned the functions. This situation is not only observed in these entities. It is the same for personal constituted under the implementation of development projects and programs launched in the agricultural sector. Issues of equality and fairness arise then one wonders whether " the woman is truly valued for her contribution into the agricultural sector ".

\section{Discussion and conclusion}

This article discusses the woman's status and her involvement in the activities regarding market garden production in Benin. It resulted that women involved in both associations of producers and government institutions related to agriculture. However, they are not represented as well as men in the different entities.

In rural areas, a significant number of women remains committed to their family farm where they are considered as workforce throughout the production process. They often do not have for the majority either a piece of land they own or material, technical, financial supports affecting their autonomy. However, women's access to these resources will enable them to produce $20-30 \%$ more food and their families would be healthier and would benefit from better nutrition and education. ${ }^{1}$ Especially in a context where issues of climate change, of erosion and soil fertility declines threaten the food security of Benin population, this extra amount of food will be of great importance. Today, if men and women had the same access to productive resources in agriculture, food production in developing countries would increase by 2.5 to 4 percent enough to eradicate hunger of 100 to 150 million individuals and contribute to achieving the Millennium development goal No. $1 .{ }^{5}$ Women continue to face difficult access to producer groups, since their membership depends exclusively on the will of the head of household. Those with the privilege of being a member of an association have their limited actions and feel a certain exclusion on important decisions. As a development potential actor, the effective participation of women in decision-making is crucial. These inequalities recorded by women brought them to gather in exclusively female group to claim their rights. But they still do not have the necessary support they need. A question of fairness is therefore necessary. In many countries, it is always rooted for many generations cultural discrimination against women preventing them from enjoying their rights as men in terms of the ownership or management of land, or issues of decision making. ${ }^{8}$ This disparity is also observed within the government institutions involved in the agricultural sector. In these entities, women are poorly represented and are very few heard when it comes to decision making. Bridging the gap between men and women in agriculture should be considered as a top priority. ${ }^{11}$ Currently, several agricultural policies, programs and projects are trying to be part of a gender mainstreaming context. They include developing policies in the context of the fight against gender inequality. They have been developed in order to end discrimination against women by ensuring equal access to resources, then the same support through agricultural programs and projects. But the results are not quite satisfactory. It is therefore to define a new framework to regulation which will indicate precisely the percentage of men and women who constitute these entities. This will improve their membership in associations of producers and allow them to be better represented government institutions as well. ${ }^{12,13}$

\section{Funding}

None.

\section{Acknowledgments}

None.

\section{Conflicts of interest}

Authors declare no conflict of interest exists.

\section{References}

1. De Groot D. Gender in value chains: a toolkit for gender mainstreaming in the development of agricultural value chains. Agri pro-focus. 2014;217.

2. Unesco. Gender equality in sub-Saharan Africa: innovative programs, perceptible results. United Nations. France;2017:107.

3. Houinsa DG. Review of the contribution of women to household resources. Rapport final. Coopération Suisse; 2013;50.

4. Houinsa DG. Review of the literature of the study on gender relations and their impact on social life in Benin. Final report. Coopération Suisse. $2013 ; 134$.

5. FAO. FAO at work 2010-2011: women, key to food security. United Nations Food and Agriculture Organization.2011;24.

6. COSP. Gender: strategic guidance document. France cooperation. 2007;41.

7. Diouf NA. Women and local development in Senegal: the role of women's associations in the groundnut basin: the example of Diourbel. Doctoral thesis. University Michel de Montaigne-Bordeaux. 2013;3:527.

8. ADB. Gender equality index in africa, empowering African women: plan of action. African Development Bank Group. 2015;42.

9. Dekens J, Vivek V. Femmes rurales, femmes de l'ombre : les partenaires clés du développement. The International Institute for Sustainable Development (IISD). 2014;6.

10. Miassi YE, Dossa KF, Labiyi AI, et al. Cashew nut production under contract in North Benin: socio-economic importance and determinants of profitability. In presss: Biotechnologie, Agronomie, Société et Environnement. 2019.

11. Carracillo C. Women - gender - development: achievements and challenges. Mutual and Fraternity. 2013;12.

12. ONU. Gender and food and nutrition security in protracted crisis: Women and girls as resilient agents. Information note. Food and Agriculture Organization of the United Nations. 2017;28.

13. UNDP. Women's contribution to household spending and poverty reduction in Maradi. Final report. United Nations. 2012;67. 